\title{
Brand extension feedback effects: A holistic framework
}

\begin{abstract}
The study modeled the impact of key brand extension variables on the change in parent brand attitudes under a holistic framework. A quantitative study was conducted to test the model using a real brand and its hypothetical brand extension. Results indicate that the two strongest effects on brand extension feedback were fit between the parent and the extension and parent brand image. The paper outlines four principles for effective brand extension design and communication strategy. A precondition for launching a brand extension is a strong parent brand. Weak parent brands should be strengthened prior to brand extensions. Once this condition is met, the design as well as the communication strategy of the brand extension should emphasize the fit with the parent using appropriate brand elements. Positive attitudes towards the extension per se should be developed to create added value perceptions for consumers. The study is also a first-of-its-kind to be conducted in India.
\end{abstract}

Keywords: Brand extensions, feedback effects, parent brand impact, India. 


\section{INTRODUCTION}

The brand extension literature has developed from evaluation of the brand extension per se to also considering the impact of the brand extensions on the parent brand, also known as the feedback effect. Feedback effects are the reciprocal impact of the brand extension on the parent brand, which can be either positive or negative. Despite substantial investigation into brand extensions, a major gap in the literature is that it is very fragmented ${ }^{1}$ and investigates feedback effects in a rather piecemeal fashion. This is partly attributable to the adoption of experimental designs in majority of the feedback literature. Consequently, there remains a dearth of empirical studies that simultaneously model the impact of key variables on parent brands. This study addresses this gap by proposing and testing a comprehensive model of brand extension feedback process as well as illuminating major effects that have previously been considered mostly in isolation.

The paper is organized into seven sections. Following this introduction, the paper discusses the development of the proposed model of brand extension feedback. This is followed by a discussion of research design and data analysis. The paper then discusses the theoretical implications followed by managerial implications. Finally, the paper acknowledges the limitations of the study and outlines pertinent future research priorities.

\section{MODEL DEVELOPMENT}

The proposed model is derived from the current theory on brand extension feedback. Essentially, from a consumer perspective, the existing framework of feedback consists of two processes, viz., process one involving evaluation of the brand extension and process two, involving re-evaluation of the parent brand, post extension launch.

Prior investigations into the evaluation of brand extensions and the subsequent feedback to the parent brand assume that a brand is a network knowledge structures consisting of attributes, benefits and attitudes held by 
the consumers ${ }^{2}$. Whenever a brand extension is launched, there is a transfer of knowledge and attitude from the parent brand to the brand extension as well as development of a perception of fit based on the number of shared associations between the parent and the extension ${ }^{3-5}$. Hence, brand extension evaluation (i.e. process one) is a function of how much the consumers know and like parent brand and the level of perceived fit between the parent brand and the extension ${ }^{6-9}$. This process is represented in the left panel of Figure 1. 
Figure 1: Two process in the brand extension literature.

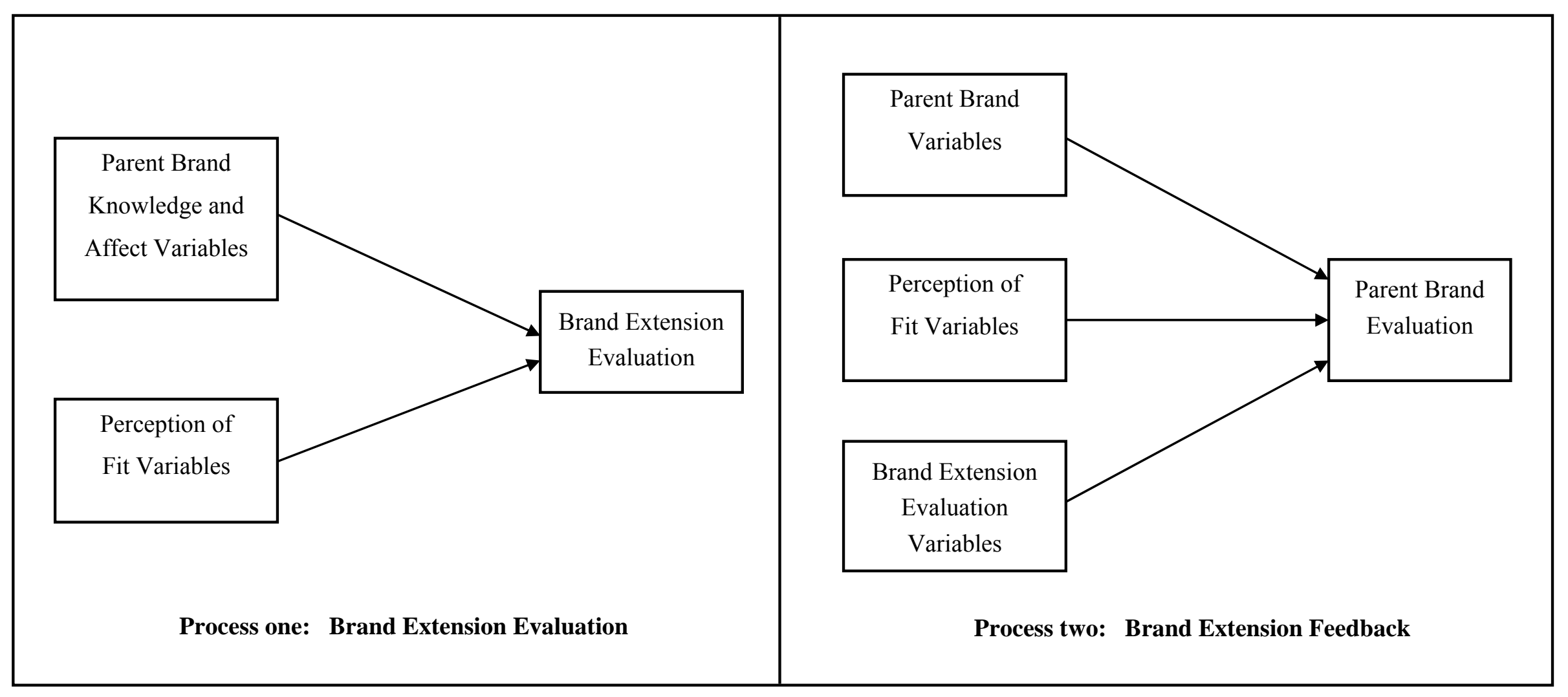


As regards the impact of brand extensions on the parent brand (i.e. process two), prior investigations assume that brand extensions possess the capability to change the consumers' existing mental schema of the parent brand. The book-keeping model of schema change ${ }^{10}$ has been forwarded as one explanation of how brand extensions impact parent brand knowledge structures. According to this model, each piece of new information (e.g. a brand extension) leads to an incremental modification of the brand's mental knowledge structure, regardless of the similarity of the new information ${ }^{10}$.

The review of the feedback literature reveals that parent brand evaluations post extension launch are mainly explained by a construct representing parent brand knowledge, a measure of similarity/fit between the parent brand and the brand extension and some measure of brand extension success/evaluation (e.g. see Chen and $\mathrm{Chen}^{11}$; Keller and Aaker ${ }^{12}$; Martinez and Chernatony ${ }^{13}$; Martinez and Pina ${ }^{14}$; Zimmer and Bhat ${ }^{15}$ ). This basic framework is represented in the right panel of Figure 1. Despite the several investigations into brand extension feedback, the literature remains fragmented and lacks a cohesive framework that investigates major influences on the parent brand simultaneously.

\section{The proposed model and its constructs}

The proposed model is presented in Figure 2. The following sections discuss each of the model's constructs along with their hypothesized effects. 
Figure 2: Proposed model of brand extension feedback

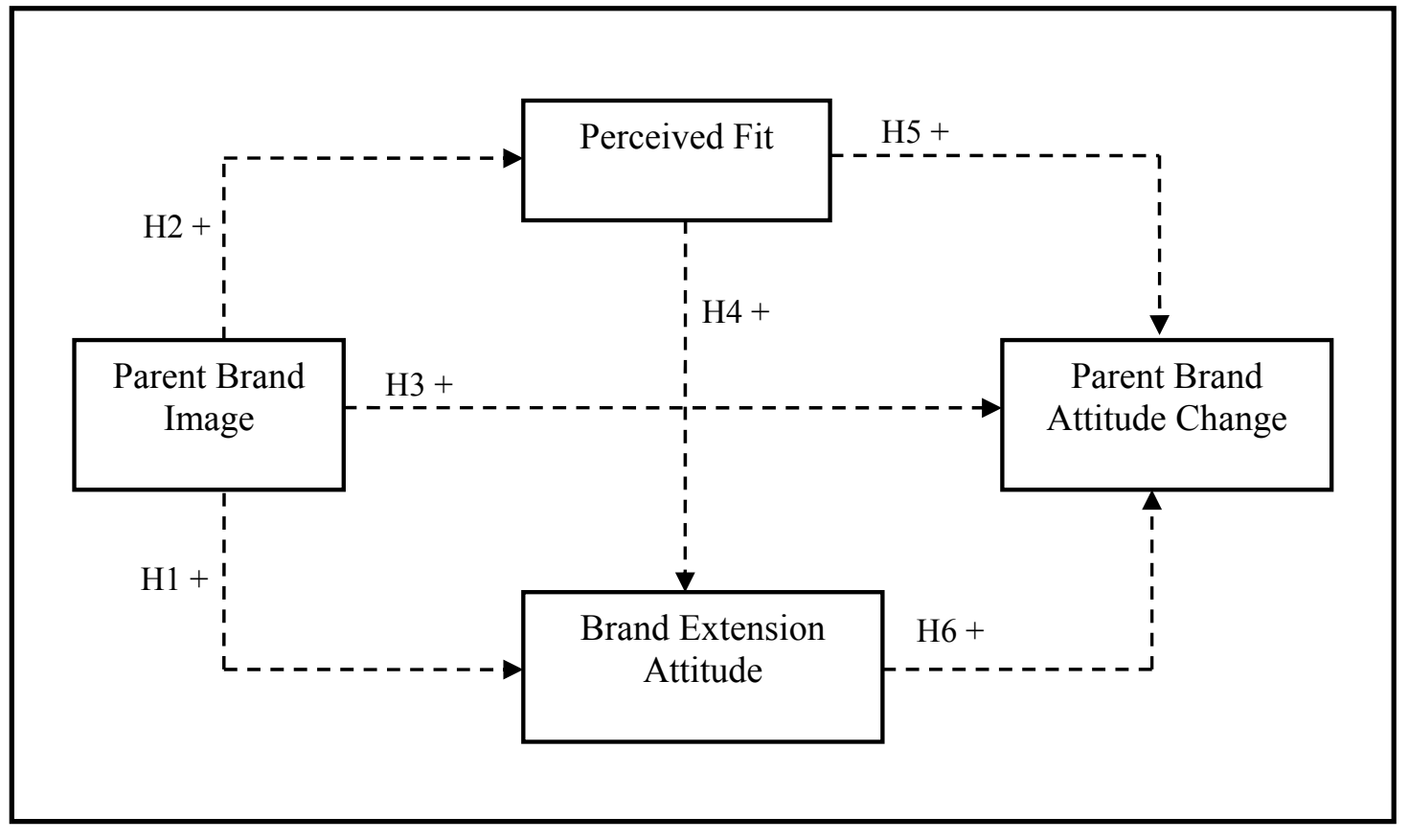

\section{Parent brand image and its effects}

In essence, a brand extension feedback process model includes a construct that represents the strength of the parent brand's existing knowledge in consumers' minds. Brand extension models require the inclusion of a variable related to measuring the existing strength of the parent brand schema, as it is the raison d'être of brand extensions to capitalize on the parent brand's name. Perceived parent brand image was chosen as it represents the number and strength of associations that consumers possess in the existing mental schema about the brand ${ }^{16,2}$ and thus, best represents consumers' brand knowledge.

Brand image is defined as the collection of both product and non-product associations in consumer memory and is developed through a synthesis made by the consumers of all the various brand signals such as brand name, visual symbols, the products it endorses, advertisements, other communications and even its reputation ${ }^{17,18}$. These associations possess the capability to effect brand extension evaluations ${ }^{2,3,6,19}$. 
Favourable brands possess greater positive attitudes among their consumers, which, in turn, facilitate the acceptance of a new product bearing the favourable brand name due to a transfer of attitude from the parent to the extension $^{3,5,7}$. The cue utilization theory ${ }^{20}$ lends further support to the effect of parent brand image on brand extension attitude, whereby the parent brand name on the brand extension serves as an extrinsic quality cue. Given that quality cues are determined through the senses prior to consumption ${ }^{21}$, brand image as an extrinsic cue takes a more important role when consumers have had no prior experience with the brand extension or when the extension is new in the market. In this situation the brand acts as an implicit cue for quality of the new product. Thus, the following hypothesis is proposed:

H1: Parent brand image positively affects attitude towards the brand extension.

Research by Park, et al. ${ }^{22}$ demonstrates that consumers may form fit perceptions not only on the basis of product-level similarity, but also on the basis of the unique image associations that arise from a particular combination of attributes and benefits. Categorization theory helps to understand the inherent dynamics. When a new product bearing the parent brand's name is launched, the consumer automatically matches it with an evoked category description ${ }^{23}$ and is likely to generalize the positive parent brand associations to the brand extension ${ }^{24}$. The greater the number of shared associations between the parent brand and the extension, greater is the perceived fit. Research by Kalamas et al. ${ }^{25}$ supports this case whereby it empirically demonstrates that parent brand attitude has a direct positive impact on consumer perceptions of brand extension fit. It is therefore hypothesized as follows:

H2: Perceived parent brand image positively affects perceived brand extension fit. 
Finally, the associative network memory theory implies that initial parent brand associations will impact on brand associations post extension launch $^{26}$. Studies by Martinez and Pina ${ }^{14}$ and Pina et al. ${ }^{27}$ confirm this relationship whereby they demonstrate that brand image after the extension is predicted by the initial brand image. When consumers see the brand name on the extension, memory structures of the parent brand are strengthened ${ }^{28}$. The relationship likely holds for initial image and parent brand attitude change after the extension, as brand attitudes like brand image, are one of the dimensions of brand associations ${ }^{29}$. Therefore the following is hypothesized:

H3: Parent brand image positively affects parent brand attitude change.

\section{Perceived fit and its effects}

A perception of fit between the extension and the parent brand is another important positive effect factor that has emerged from the brand extension literature ${ }^{3,8,30}$. Although consensus exists regarding the importance of perceived fit in brand extension evaluation as well as brand extension feedback to the parent brand, no consistent conceptualization of fit has emerged $^{3,31}$. Some researchers adopt a feature overlap view of fit ${ }^{6,32}$ and some conceptualize fit beyond physical attribute similarity (e.g. Park, et al. $^{22}$; Broniarczyk and $\mathrm{Alba}^{7}$ ).

In light of the argument on conceptualization of fit, Park, et al. ${ }^{22}$ caution researchers that the presence or absence of identifiable relationships between existing brand products may not be the only basis on which consumer judge perceived fit. This is supported by Murphy and Medin's ${ }^{33}$ claim that consumers form their own theories of fit while judging brand extensions. Keller ${ }^{2}$ even states that any association held in consumer memory about the parent brand may serve as a potential basis of fit. So, in order to accommodate this flexible perspective on fit, this research adopts Tauber's ${ }^{34}$ conceptualization of perceived fit that it refers to the extent to 
which 'consumers accept the new product as logical and would expect it from the [parent] brand' (p.28). This logical or commonsensical approach not only accommodates Murphy and Medin's ${ }^{32}$ claim of consumers forming their own theories of fit and but also Keller's ${ }^{2}$ claim of any association acting a basis of fit. Since the purpose of the study is not to understand consumers' underlying basis of perceived fit, Tauber's ${ }^{34}$ conceptualization of the extension being perceived as a logical product from the parent brand was adopted for this research.

The well accepted paradigm in the brand extension literature is that, as the similarity of associations between the parent brand and the extension increases, so will a schematic fit between the brand and the extension and vice versa ${ }^{35}$ leading to a greater transfer their attitude from the parent to the extension $^{4}$. A plethora of past research has established a positive explanatory role of fit in brand extension evaluation (e.g. Aaker and Keller ${ }^{6}$; Bhat and Reddy ${ }^{3}$; Bottomley and Holden, ${ }^{36}$, Boush and Loken ${ }^{31}$; Keller and Aaker $^{12}$; Klink and Smith ${ }^{37}$; Park, et al. $^{22}$ ). So, in coherence with the accepted paradigm, the following hypothesis is proposed:

H4: Brand extension fit with the parent brand positively affects attitude towards the brand extension.

Brand extensions possess the capability to change parent brand attitudes and beliefs by way of creating new associations with the parent brand ${ }^{38}$. Prior brand extension feedback has empirically highlighted the role of perceived fit in feedback to the parent brand (e.g. Aaker and Keller ${ }^{6}$; Bottomley and Doyle $^{39}$; Martinez and Pina ${ }^{14}$; Martinez and Chernatony ${ }^{13}$; Loken and Roedder-John ${ }^{40}$; Zimmer and Bhat ${ }^{15}$ ). Perceived fit has been shown to have enhancement effects $^{10,15,41}$ as well as dilution effects ${ }^{13,14,42}$ on the parent brand.

The reason for this effect is that a good fit is likely to strengthen beliefs and associations leading to a strong brand positioning ${ }^{5}$ and in turn enhancing parent brand attitude, while a poor fit is expected to create negative 
associations that create negative attitudes towards the parent brand ${ }^{10,12,13}$. Thus, the change brought about in the mental schema is likely to be reflected in the change in parent brand attitude. Hence the following is hypothesized:

H5: Brand extension fit with the parent brand positively affects parent brand attitude change.

\section{Attitude towards the brand extension and its effects}

Attitude towards the brand extension was chosen as the third variable in the model. The rationale behind its inclusion was that a measure of brand extension success or failure creates vital initial reactions towards the parent brand. Ample evidence in the feedback literature lends credence to the importance of this variable (e.g. Chen and Chen ${ }^{11}$; Keller and Aaker ${ }^{12}$; Martinez and Chernatony ${ }^{13}$; Sheinin ${ }^{38}$ ) given that the feedback process originates only after the extension is launched in the market and receives initial evaluations from the consumers.

Prior literature on feedback effects has shown that attitudes to the brand extension affect parent brand evaluations ${ }^{10,13,43}$. This effect could be understood using schema change theories that claim that attitudes and beliefs held in memory about the parent brand change in response to brand extensions ${ }^{44,45}$. This research proposes that the evaluation of the parent brand is more likely to be positive if consumers hold positive attitudes towards the extension. Sheinin ${ }^{38}$ observed that positive 'extension-derived beliefs' (p.48) led to favourable evaluations of the parent brand. Similar results were observed by Martinez and Chernatony ${ }^{13}$. On the other hand, if consumers possess negative attitudes towards the extension, this will transfer to the parent brand and as a result, the parent brand associations in the mental schema are likely to be weakened, thus leading to a dilution effect. The following hypothesis is therefore forwarded: 
H6: Attitude towards brand extension positively affects on parent brand attitude change.

\section{Parent Brand Attitude Change}

As regards the choice of the dependent variable, parent brand attitudes were chosen as the evaluative dimension because of their key importance in developing overall brand equity ${ }^{1,6}$. Choosing parent brand attitudes as the dependent variable is in congruence with most of the feedback literature (e.g. Ahluwalia and Gurhan-Canli ${ }^{42}$; Keller and Aaker ${ }^{12}$; Lane and Jacobsen ${ }^{46}$; Milberg et al. $^{40}$; Zimmer and Bhat ${ }^{15}$ ). However, despite the substantial literature investigating the impact of brand extensions on parent brand attitudes, there still remains a lack of clarity on the nature of impact and hence a need to clarify the issue ${ }^{15}$. The focus of this study is to investigate the impact on the change in parent brand attitudes, as feedback effects have been conceptualized as a change in the mental schema of the parent brand ${ }^{10}$. Thus, the dependent variable in the study is labelled parent brand attitude change.

\section{RESEARCH DESIGN}

A self-administered quantitative survey of 387 young male subjects (all 1825 yrs of age) from a university college in the capital city of New Delhi was conducted by handing out the survey in lectures. Missing data was less than three percent of the usable responses and was replaced by the meansubstitution method. The sample size selected was well above 200, which is generally considered a minimum requirement for conducting a structural equation modeling (SEM) analysis ${ }^{47}$. It was ensured that the chosen sample matches the target market for the chosen industry, i.e. young urban males in the 18-25 year age group (i.e. generation Y) belonging to middle to upper income households. 


\section{Stimulus Selection}

A real brand and its hypothetical extension were chosen as stimulus in this research which was in line with prior brand-extension literature. The Indian men's fashion footwear sector was chosen for the study due to its high popularity among young male consumers belonging to upper-middle to upper-income households. This segment closely matched the sample chosen in this study. Another consideration in stimulus selection was that only well known brand names be examined for their potential to be extended, as fictitious brands do not carry well-formed associations and feelings that are requisite for brand extension ${ }^{48}$. Therefore, to arrive at a well-known parent brand, a few exploratory informal discussions were held with small groups of subjects, with eight to ten participants in each. The participants were asked to mention their favourite brand from the ones they had previously purchased. The popular Indian fashion footwear brands that were most mentioned by the groups were Lee Cooper, Provogue, Woodland and Red Tape. The brand Woodland was randomly chosen as the parent brand from the options. Secondary data revealed that Woodland currently owns around forty percent of the casual premium shoe market, has a retail presence across the India and is planning future expansion into other product categories.

Branded sunglasses category was predetermined as the probable extension category for this research. The rationale in doing so was the current trend among Indian fashion brands to provide lifestyle solutions for their consumers by extending into other lifestyle product categories like watches, leather garments, lingerie and eyewear, especially to the 18-25 year demographic. Thus, the hypothetical brand-extension scenario used as stimulus in the study was the launch of Woodland sunglasses. It was clarified in the questionnaire that the scenario of Woodland launching Woodland sunglasses was purely hypothetical. 


\section{Construct Measures}

The measures for all the constructs were based on a seven-point Likert scale. They were anchored as strongly disagree (1) to strongly agree (7) which is consistent with previous brand extension research. The dependent and independent variables were created by aggregating the scores and dividing by the number of items. Five items were used to measure initial parent brand image and were adopted from Martinez and Chernatony ${ }^{13}$. Perceived fit of the brand extension was assessed using four items that were constructed based on Tauber' ${ }^{34}$ definition of fit. This study operationalized extension success in terms consumer attitudes towards the extension. The items used to measure brand extension attitude were adapted from Lane and Jacobsen ${ }^{46}$.

The items used to measure the change in attitude towards the parent brand as a consequence of brand extension were anchored as more strongly negative attitude to Woodland as compared with before (1) and more strongly positive attitude towards Woodland as compared with before (7), with a mid-point of same attitude towards Woodland as compared with before (4). A measure of the change in attitude in the parent brand to measure feedback effect was used to avoid noise that would arise in the measure of the level of parent brand attitude, after and before the change (and then measure the difference in the level of the parent brand attitude). The items measuring the parent brand attitude change were based on the same items that measured brand extension attitude, but set differently to capture change in the parent brand, as mentioned above. Exploratory factor analysis (EFA) conducted on the data revealed that all items loaded strongly their respective factors except one item from the parent brand image scale. It was deleted from the SEM analysis. Table 1 lists the constructs and the items used to measure them. 
Table 1: Constructs and their items

\begin{tabular}{|c|c|}
\hline Construct & $\begin{array}{c}\text { Items } \\
\text { (measured on a 7-point Likert scale) }\end{array}$ \\
\hline Parent brand image (PBI) & $\begin{array}{l}\text { 1. The Woodland brand is interesting. } \\
\text { 2. The Woodland brand has personality. } \\
\text { 3. According to me, Woodland is different from other competing brands. } \\
\text { 4. I feel that I have a clear reason to buy Woodland instead of others. } \\
\text { 5. I have a clear impression of the type of people who use Woodland. }\end{array}$ \\
\hline Perceived fit (FIT) & $\begin{array}{l}\text { 1. The sunglasses extension by Woodland makes sense. } \\
\text { 2. According to me, the decision to launch Woodland Sunglasses is very surprising. } \\
\text { 3. According to me Woodland's decision to launch sunglasses seems logical. } \\
\text { 4. The launch of sunglasses by Woodland in the market was expected. }\end{array}$ \\
\hline $\begin{array}{l}\text { Brand extension attitude } \\
\text { (ATBE) }\end{array}$ & $\begin{array}{l}\text { 1. My attitude towards Woodland sunglasses is very positive. } \\
\text { 2. I am very favourably disposed towards Woodland sunglasses. } \\
\text { 3. According to me Woodland sunglasses are great. } \\
\text { 4. I admire Woodland sunglasses a lot. } \\
\text { 5. I feel good about Woodland sunglasses. }\end{array}$ \\
\hline $\begin{array}{l}\text { Parent brand attitude change* } \\
\text { (PBAC) }\end{array}$ & $\begin{array}{l}\text { 1. My attitude towards Woodland would become.. } \\
\text { 2. My disposition towards Woodland and its products would become.. } \\
\text { 3. My opinion regarding Woodland as a great brand would become.. } \\
\text { 4. My admiration towards Woodland would become.. } \\
\text { 5. My opinion regarding Woodland as having a great reputation would become.. }\end{array}$ \\
\hline
\end{tabular}

*Note: The variable was anchored from -3 (Strongly negative as compared with before) to + 3 (Strongly positive as compared with before). 


\section{DATA ANALYSIS AND RESULTS}

The results of the study are presented in sections. First, the issue of construct reliability and validity is addressed. This is followed by the two-step SEM approach as proposed by Andersen and Gerbing ${ }^{49}$. First, the analysis of the measurement-model (using confirmatory factor analysis) was conducted followed by the specification and analysis of the structural model to gauge the model's fit to the data and to test the hypotheses. The software AMOS 5.0 was used for running the SEM analyses.

\section{Construct Reliability and Validity}

Prior to the SEM analysis, tests of construct reliability and validity were performed on the data. First of all, reliability was estimated using two indices. The constructs of parent brand image (PBI), perceived fit (FIT), attitude towards the brand extension (ATBE) and parent brand attitude change (PBAC) had acceptable construct reliabilities of $0.77,0.81,0.76$ and 0.78 , respectively, each above Garver and Mentzer's ${ }^{50}$ recommended cut-off of 0.70 . Also the Cronbach Alpha measure of reliability for each of the constructs was $0.76,0.80,0.75$ and 0.77 , for PBI, PF, ATBE and PBAC respectively; each above the recommended level of 0.70 .

Convergent validity was assessed using two tests. First, the magnitude, sign and the significance of the factor loadings were examined after conducting confirmatory factor analysis in AMOS 5.0. All the factors loadings were highly significant and they all loaded strongly on their respective constructs supporting convergent validity. This was followed by the average variance extracted (AVE) test suggested by Fornell and Larcker $^{51}$. The AVE score for each of the constructs was $0.62,0.68,0.61$ and 0.64 for PBI, PF, ATBE and PBAC, respectively, higher than the recommended 0.50 level $^{51}$.

Unidimensionality was also diagnosed using the Cronbach alpha test and the factor analysis test as per the guidelines presented in Cohen $^{52}$ and Hutcheson and Sofroniou $^{53}$. The Cronbach alphas for all the constructs were satisfactory as outlined in the previous section. Further, principal component factor analysis using varimax rotation was conducted taking items for two constructs at a time. Indicators demonstrated higher factor loadings on their own constructs than on other constructs 
for all pairs used. This procedure was conducted for all combinations of items taking items for two constructs at a time. Thus, unidimensionality was supported.

Finally, consistent with the recommendations of Fornell and Larker ${ }^{51}$, discriminantvalidity is fulfilled if the variance extracted for each pair of constructs is greater than their respective squared-correlations. Table 2 outlines the variance extracted and squared-correlations for each pair of constructs. The inter-construct varianceextracted figures are typed as bold and italicized. For each pair of constructs, the variance extracted was greater than the respective inter-construct squared correlations, thus fulfilling the discriminant validity condition.

Table 2: Comparing inter-construct squared-correlation and variance extracted

\begin{tabular}{|l|l|l|l|l|}
\hline Constructs & PBI & FIT & ATBE & PBAC \\
\hline Parent brand image (PBI) & -- & $\mathbf{0 . 5 5}$ & $\mathbf{0 . 5 4}$ & $\mathbf{0 . 5 2}$ \\
\hline Perceived fit (FIT) & 0.02 & -- & $\mathbf{0 . 5 9}$ & $\mathbf{0 . 5 7}$ \\
\hline Attitude towards brand-extension (ATBE) & 0.07 & 0.21 & -- & $\mathbf{0 . 5 5}$ \\
\hline Parent-brand attitude change (PBAC) & 0.07 & 0.21 & 0.17 & -- \\
\hline
\end{tabular}

\section{Measurement Model Assessment}

The overall fit of the measurement model was then assessed. The fit statistics used to test model fit were the chi-square/degrees-of-freedom ratio $\left(\chi^{2} /\right.$ d.f. $)$ or the Normed chi-square, goodness of fit index (GFI), normed fit index (NFI, Bentler and Bonnet ${ }^{54}$ ), comparative fit index (CFI, Bentler ${ }^{55}$ ) and the root mean square error of approximation (RMSEA). Goodness-of-fit indices apart from the chi-square $\left(\chi^{2}\right)$ were adopted as the chi-square measure is sensitive to sample size, especially for cases in which the sample size exceeds 200 respondents $^{56}$. The measurement model yielded acceptable fit statistics with a significant chi-square value $(258.15 ; \mathrm{p}<0.05)$, Normed chi-square $=1.81, \mathrm{GFI}=0.94, \mathrm{NFI}=0.91$ and $\mathrm{CFI}=0.95$. No evidence of major misfit between the data and the model was observed, as the RMSEA value of 0.044 , below Browne's ${ }^{57}$ criteria of 0.05 was obtained. The conclusion was that the construct measures were valid. The next step in the analysis moves from measurement to model estimation. 


\section{Structural Model Fit and Parameter Estimates}

The structural model analysis yielded an expected significant chi-square (237.81; $\mathrm{p}<0.05)$ given the large sample size ${ }^{58}$. Other fit indices were used to support the Chisquare criterion. A Normed chi-square of 1.37, GFI of 0.96, NFI of 0.92, a CFI of 0.98 , and an RMSEA value of 0.034 indicated an adequate fit. The tests for the hypotheses were conducted next by examining the significance of the latent variable path estimates. Table 3 reports the standardized path estimates (or beta coefficients), critical ratios (C.R.) and the respective significance levels. Values in excess of 1.96 for critical ratios indicate significance ${ }^{58}$.

Table 3: Standardized path estimates of the structural model

\begin{tabular}{|l|l|c|c|c|l|}
\hline Hypothesis & $\begin{array}{c}\text { Latent Variable } \\
\text { Path }\end{array}$ & $\begin{array}{c}\text { Standardized } \\
\text { Estimates }\end{array}$ & $\begin{array}{c}\text { Critical } \\
\text { Ratios }\end{array}$ & $\begin{array}{c}\text { Sig. } \\
\text { Level }\end{array}$ & $\begin{array}{c}\text { Hypotheses } \\
\text { Support }\end{array}$ \\
\hline H1 & PBI $\rightarrow$ ATBE & 0.21 & 3.39 & 0.000 & Accepted \\
\hline H2 & PBI $\rightarrow$ FIT & 0.20 & 3.04 & 0.002 & Accepted \\
\hline H3 & FIT $\rightarrow$ ATBE & 0.50 & 6.35 & 0.000 & Accepted \\
\hline H4 & FIT $\rightarrow$ PBAC & 0.52 & 5.89 & 0.000 & Accepted \\
\hline H5 & ATBE $\rightarrow$ PBAC & 0.14 & 1.77 & 0.06 & $\begin{array}{l}\text { Marginally } \\
\text { Accepted }\end{array}$ \\
\hline H6 & PBI $\rightarrow$ PBAC & 0.17 & 2.78 & 0.005 & Accepted \\
\hline
\end{tabular}

As Table 3 shows, all of the six hypotheses were supported. The impact of parent brand image on brand extension evaluation was significant $(\beta=0.21, \mathrm{CR}=3.39)$, thus hypothesis $\mathrm{H} 1$ is supported. The impact of parent brand image on perceived fit was significant as well $(\beta=0.20, \mathrm{CR}=3.04)$. Hypothesis $\mathrm{H} 2$ was thus accepted. Effect of perceived fit on evaluation of brand extension was also significant $(\beta=0.50, \mathrm{CR}=$ 6.35). H3 was therefore accepted. Further, the path from perceived fit to parent brand attitude change was significant $(\beta=0.52, \mathrm{CR}=5.89)$, thus hypothesis $\mathrm{H} 4$ was thus accepted. The impact of brand extension evaluation on parent brand attitude change was marginally significant ( $\beta=0.14, \mathrm{CR}=1.77$ ); thus hypothesis H5 was marginally accepted. Finally, the impact of parent brand image on parent brand attitude change was significant $(\beta=0.17, \mathrm{CR}=2.78)$. Hypothesis $\mathrm{H} 6$ was therefore accepted. 


\section{DISCUSSION}

The study contributes to the brand extension feedback literature as follows:

- Presenting a holistic framework for analyzing brand extension feedback effects.

- Presenting a rank order of major determinants of brand extension feedback effects.

- Emphasizing a special focus on the importance and integrating role of fit.

- Modeling the effects on the change in parent brand attitude.

The first contribution of the study is that it enhances the understanding of the brand extension feedback effects by investigating them using a holistic model. The holistic model includes a two-stage process, viz., brand extension evaluation followed by feedback effect of the brand extension. This holistic approach also includes a comprehensive explanation of feedback, with three independent variables acting together. Previously multiple feedback effect studies have failed to consider interrelationships among explanatory variables (e.g. Martinez and Pina ${ }^{14}$; Volkner et al. ${ }^{59}$ ). On the other hand, studies that consider inter-relationships fail to observe a feedback effect of fit towards general brand image ${ }^{26}$.

The second contribution of the study is a clear ranking of the major determinants of feedback effects on the parent brand when considered simultaneously. This rank order is more meaningful and realistic as it considers inter-relationships among the key brand extension variables. The ranking of effects is as follows:

1. Perceived fit;

2. Parent brand image;

3. Brand extension attitude.

Fit has always been the most dominant force in explaining extension success as well as feedback effects in most part of the literature. Under this holistic framework, the number one position of fit was solidified. This result is consistent with prior literature (e.g. Bottomley and Holden ${ }^{36}$; Broniaczyk and Alba ${ }^{7}$; Grime et al. ${ }^{1}$; Keller and Aaker ${ }^{14}$; Milberg et. al. ${ }^{40}$ ). 
Based on the popularity and frequency in the prior literature, brand extension success as a determinant of feedback is placed at a number two spot. However, results of the study place it at number three. This effect of extension attitude on the parent brand feedback is in congruence with earlier findings in the literature (e.g. Martinez and Chernatony $^{13}$; Martinez, et al. ${ }^{59}$; Pina et al. ${ }^{27}$ ). This study has clarified its likely true position.

Based on its relative minor presence in the feedback literature, parent brand image as determinant of brand feedback was expected to be at number three. In fact, it emerged as a number two determinant of brand extension feedback. The associative network memory theory ${ }^{2}$ explains this effect whereby consumers' initial brand associations have a positive effect on final brand attitudes. These results complement previous findings by Martinez and Pina ${ }^{14}$ and Pina et al. ${ }^{27}$ who observed a direct effect of initial brand image on brand image after the extension. However, it needs to be further investigated in future studies.

The third contribution is a fresh perspective on the importance and integrating role of fit. Fit strongly affected both extension evaluation as well as the change in parent brand attitude. Herein lays the integrating role of fit that has not been explicitly discussed before. Brand extensions initially rely on fit with the parent brand to make inroads into the new market. On the flip side, the same fit ensures a positive feedback to the parent brand as well. This integrating mechanism of fit can be considered analogous to that of a pneumatic tube mechanism. Fit first travels along in one direction to strengthen the brand extension in the new market and then recoils back to the parent brand as a form of dividend (enhanced parent brand attitude).

Theoretically, both categorization theory and the bookkeeping model of schemachange explain this mechanism. Once consumers perceive a fit between the parent and the extension, there is a transfer of positive attitude to the extension via categorization process. In turn, the good fit leads to the creation of positive associations that positively enhance the mental schema of the parent brand ${ }^{10,39}$. 
The fourth contribution is an alternative approach to estimating the change in the outcome variable. The explanatory effects were modelled on the change in parent brand attitudes, as feedback is conceptualized as a change in the mental schema of the parent brand. This study assesses the change in parent brand attitude within a single scale. This way of measuring feedback effect on the parent brand has facilitated the richer understanding of major determinants. A small number of studies (e.g. Völkner et al. ${ }^{58}$; Grime et al. ${ }^{1}$ ) do use the change in dependent variable, but not within the same scale.

\section{MANAGERIAL IMPLICATIONS}

The results have managerial implications which have been formulated as a set of four principles for brand extensions:

- Principle 1: The 'go - no go' decision for a brand extension;

- Principle 2: Designing the brand extension;

- Principle 3: Promoting the brand extension;

- Principle 4: Designing a total brand extension design and communication strategy.

The first principle is whether to commence designing a brand extension or not. The results suggest that weak parent brands should not be extended until they have been strengthened and refreshed. Stock market investigations have revealed that the market reacts favourably to brand extension announcements that are made by firms with higher consumer attitudes in the marketplace ${ }^{60}$. Thus, prior investment in the parent brand may be needed before embarking on the brand extension.

When the parent brand is considered strong enough, consideration can be given to designing a brand extension (Principle 2). The results suggest that a key principle in design should be a close fit to the parent brand. This is achieved through choosing appropriate brand elements that are consistent with the parent brand. Examples include the use of consistent packaging as well as the use of brand's lettering and colour. Apart from ensuring brand extension acceptance, it would also ensure a positive contribution to the parent brand. 
Implications also exist regarding promotional decisions (Principle 3). Given the central importance of fit, all communications designed for the brand extension should focus on enhancing links with the parent brand's core values. This necessitates communicating the fit between the parent brand and the extension through appropriate positioning of the extension, for example, positioning of Olay vitamins as beauty products and not health supplements. Developing attitudes towards the brand extension are also crucial as consumers' first impressions with the extension matter. Research with managers has shown that they are interested in generating quick initial adoption of the extension ${ }^{61}$. The promotional campaign should develop stronger consumer attitudes towards the extension to create a perception of value in the brand extension per se so that the extension becomes self-sustaining in the long run.

Consumer needs are getting fragmented and corporations expect managers to launch brands and brand extensions in order to meet those emerging needs ${ }^{62}$. A potential risk for mangers is when they launch a successful brand extension that diminishes the parent brand equity ${ }^{63}$. Brand extension success alone does not automatically guarantee positive feedback effects. In the era of brand consolidation, if brand extensions fail to contribute to the parent in a substantial manner, their viability as a strategic marketing investment is questioned. A good fit with the parent brand ensures a double return, i.e. brand extension acceptance as well as contribution to overall brand equity (or feedback). Thus, it is crucial for brand managers to adopt an appropriate brand extension design and communications strategy (Principle 4). Principle four combines the preceding three principles into a coherent brand extension plan.

\section{LIMITATIONS AND FUTURE RESEARCH}

The purpose of limitations is not to undermine the results of the research but to establish its boundaries. The first limitation regards the conceptualization of perceived fit as envisaged in this research. This was limited to evaluating how logical and sensible was the brand extension in the consumers' eyes. Literature has suggested various other conceptualizations of fit between the parent brand and the extension and future research could model feedback effects using these alternative conceptualizations of perceived fit. Further, this research investigated the impact of 
brand extensions on the change in only one outcome variable, i.e. parent brand attitude. Future research may be conducted to gauge the impact of the brand extension on the change in other aspects of the parent brand. This would add more depth to the understanding of feedback effects.

Furthermore, this research acknowledges that there may be moderating effects on the model, but as an important first step towards analyzing simultaneous effects of variables, only the direct effects were modelled. Future research should consider including moderating effects of either marketing-related or consumer-related factors on the model. Finally, future research should consider replicating the model across other product categories as well in the context of service and retail industry brand extensions. Such replication would enrich the theoretical knowledge on brand extension feedback effects as well as to achieve global validity. 


\section{References}

1. Grime, I. Diamantopoulos, A. and Smith, G. (2002) 'Consumer evaluations of extensions and their effects on the core brand: Key issues and research propositions', European Journal of Marketing, Vol. 36, No. 11/12, pp. 14151447.

2. Keller, K. L. (2003) 'Strategic brand management: Building, Measuring and Managing Brand Equity', Prentice Hall, New Jersey.

3. Bhat, S and Reddy, S. K. (2001) 'The impact of parent brand attribute associations and affect on brand extension evaluation', Journal of Business Research, Vol. 53, No. 3, pp. 111-122.

4. Czellar, S. (2003) 'Consumer attitude toward brand extensions: An integrative model and research propositions', International Journal of Research in Marketing, Vol. 20, No. 1, pp. 97-115.

5. Sheinin, D. A. (1998) 'Positioning brand extensions: Implications for beliefs and attitudes', Journal of Product and Brand Management, Vol. 7, No. 2, pp. 137-149.

6. Aaker, D. A. and Keller, K. L. (1990) 'Consumer evaluations of brand extensions', Journal of Marketing, Vol. 54, No. 1, pp. 27-41.

7. Broniarczyk, S. M. and Alba, J. W. (1994) 'The Importance of the Brand in Brand Extension', Journal of Marketing Research, Vol. 31, No. 2, pp. 214228.

8. Hem, L. and Iversen, N. M. (2002) 'Decomposed similarity measures in brand extensions', Advances in Consumer Research, Vol. 29, No. 1, pp. 199-206. 
9. McCarthy, M. S., Heath, T. B. and Milberg, S. J. (2001) 'New brands versus brand extensions, attitudes versus choice: Experimental evidence for theory and practice', Marketing Letters, Vol. 12, No. 1, pp. 75-90.

10. Gurhan-Canli Z. and Maheswaran, D. (1998) 'The effects of extensions on brand name dilution and enhancement', Journal of Marketing Research, Vol. 35, No. 4, pp. 464-473.

11. Chen, A. C-H. and Chen, S. K. (2000) 'Brand dilution effect of an extension failure: A Taiwan study', Journal of Product and Brand Management, Vol. 9, No. 4, pp. 243-254.

12. Keller, K. L. and Aaker, D. A. (1992) 'The effects of sequential introduction of brand extensions', Journal of Marketing Research, Vol. 29, No. 1, pp. 3550.

13. Martinez, E. and Chernatony, L. D. (2004) 'The effect of brand extension strategies on brand image. Journal of Consumer Marketing, Vol. 21, No. 1, pp. 39-50.

14. Martinez, E. and Pina, J. A. (2003) 'Negative impact of brand extensions on parent brand image', Journal of Product and Brand Management, Vol. 12, No. 6/7, pp. $432-448$.

15. Zimmer, M. R. and Bhat, S. (2004) 'The reciprocal effects of extension quality and fit on parent brand attitude', The Journal of Product and Brand Management, Vol. 13, No. 1, pp. 37-46.

16. Hem, L., Chernatony L. D., and Iversen N. M., (2003) 'Factors influencing successful brand extensions', Journal of Marketing Management, Vol. 19, No. 7-8, pp.781-806. 
17. Kapferer, J. N. (2002) 'Strategic Brand Management: Creating and Sustaining Brand Equity Long Term', Kogan Page India Pvt. Limited, New Delhi, India.

18. Kwun, D. J-W. and Oh, H. (2007) 'Consumer evaluation of brand portfolios', International Journal of Hospitality Management, Vol. 26, No. 1, pp. 81-97.

19. Supphellen, M. (2000) 'Understanding core brand equity: Guidelines for indepth elicitation of brand associations', International Journal of Market Research, Vol. 42, No. 3, pp. 319-338.

20. Richardson, P. S., Dick, A. S. and A.K. Jain (1994) 'Extrinsic and intrinsic cue effects on perceptions of store brand quality', Journal of Marketing, Vol. 58, No. 1, pp. 28-36.

21. Steenkamp, J.-B.E.M., (1990) 'Conceptual model of the quality perception process', Journal of Business Research, Vol. 21, No. 4, pp. 309-333.

22. Park, C. W., Milberg, S. J., Lawson, R. (1991) 'Evaluation of brand extensions: The role of product feature similarity and brand concept consistency', Journal of Consumer Research, Vol. 18, No. 2, pp. 185-193.

23. Goodstein, R. C. (1993) 'Category-based applications and extensions in advertising: Motivating more extensive ad processing, Journal of Consumer Research, Vol. 20, No. 1, pp. 87-99.

24. Gronhaug, K., Hem, L. and Lines, R. (2002) 'Exploring the impact of product category risk and consumer knowledge in brand extensions', Journal of Product and Brand Management, Vol. 9, No. 6, pp. 463-476.

25. Kalamas, M., Cleveland, M., Laroche, M. and Laufer, R. (2006) 'The critical role of congruency in prototypical brand extensions', Journal of Strategic Marketing, Vol. 14, No. 3, pp. 193-210. 
26. Martinez, E., Polo, Y. and Chernatony, L. D. (2008) 'Effect of brand extension strategies on brand image: A comparative study of the UK and Spanish markets', International Marketing Review, Vol. 25, No. 1, pp. 107-137.

27. Pina, J. M., Martinez, E., Chernatony, L. D. and Drury, S. (2006) 'The effect of service brand extensions on corporate image: An empirical model', European Journal of Marketing, Vol. 40, No. 1/2, pp. 174-197.

28. Morrin, M. (1999) 'The impact of brand extensions on parent brand memory structures and retrieval processes', Journal of Marketing Research, Vol. 36, No. 4, pp. 517-525.

29. Low, G. S. and Lamb, C. W. Jr. (2000) 'The measurement and dimensionality of brand associations', Journal of Product and Brand Management, Vol. 9, No. 6, pp. 350-368.

30. Zhang, S. and Sood, S. (2002) 'Deep' and 'surface' cues: Brand extension evaluations by children and adults', Journal of Consumer Research, Vol. 29, No. 1: pp. 129-141.

31. Bridges S., Keller, K. L. and Sood, S. (2000) 'Communication strategies for brand extensions: Enhancing perceived fit by establishing explanatory links', Journal of Advertising, Vol. 29, No. 4, pp. 1-11.

32. Boush, D. M. and Loken, B. (1991) 'A process-tracing study of brand extension evaluation', Journal of Marketing Research, Vol. 28, No. 1, pp.1628.

33. Murphy, G., and Medin, D. (1985) 'The role of theories in conceptual coherence', Psychological Review, Vol. 92, No. 3, pp. 289-316.

34. Tauber, E. M. (1988) 'Brand leverage: Strategy for growth in a cost controlled world', Journal of Advertising Research, Vol. 28, No. 4, pp. 26-30. 
35. Meyvis, T. and Janiszewski, C. (2004) 'When are broader brands stronger brands? An accessibility perspective on the formation of brand equity', Journal of Consumer Research, Vol. 31, No. 2, pp. 346-357.

36. Bottomley, P. A. and Holden, S. J. S. (2001) 'Do we really know how consumers evaluate brand extensions: Empirical generalizations based on secondary analysis of eight studies', Journal of Marketing Research, Vol. 38, No. 4, pp. 494-500.

37. Klink, R. R. and Smith, D. C. (2001) 'Threats to external validity of brand extension research. Journal of Marketing Research, Vol. 38, No. 3, pp. 326335.

38. Sheinin, D. A. (2000) 'The effects of experience with brand extensions on parent brand knowledge', Journal of Business Research, Vol. 49, No. 1, pp. $47-55$.

39. Bottomley, P. A. and Doyle J. R. (1996) 'The formation of attitudes towards brand extensions: testing and generalizing Aaker and Keller's model', International Journal of Research in Marketing, Vol. 13, No. 4, pp. 365-377.

40. Loken, B. and Roedder-John D. R. (1993) 'Diluting brand beliefs: when do brand extensions have a negative impact?' Journal of Marketing, Vol. 57, No. 3, pp. 71-84.

41. Milberg, S. J., Park, C. W. and McCarthy, M. S. (1997) 'Managing negative feedback effects associated with brand extensions: The impact of alternative branding strategies', Journal of Consumer Psychology, Vol. 6, No. 2, pp.119140. 
42. Thorbjornsen, H. (2005) 'Brand extensions: Brand concept congruency and feedback effects revisited', Journal of Product and Brand Management, Vol. 14, No. 4, pp. 250-257.

43. Ahluwalia, R. and Gurhan-Canli, Z. (2000) 'The effects of extensions on the family brand name: an accessibility-diagnosticity perspective', Journal of Consumer Research, Vol. 27, No. 3, pp. 371-381.

44. Chen, K. J. and Liu, C. M. (2004) 'Positive brand extension trial and choice of parent brand', Journal of Product and Brand Management, Vol. 13, No. 1, pp. 25-36.

45. Park, C. W., McCarthy, M. S. and Milberg, Sandra, J. (1993) 'The effects of direct and associative brand extension strategies on consumer response to brand extensions', Advances in Consumer Research, Vol. 20, No. 1, pp. 28-33.

46. Lane, V. and Jacobson, R. (1997) 'The reciprocal impact of brand leveraging: Feedback effects from brand extension evaluation to brand evaluation', Marketing Letters, Vol. 8, No. 3, pp. 261-271.

47. Kline, R. B. (1998) 'Principles and Practice of Structural Equation Modeling', Guilford Press, New York.

48. Martin, I. M. and Stewart, D. W. (2001) 'The differential impact of goal congruency on attitudes, intentions, and the transfer of brand equity', Journal of Marketing Research, Vol. 38, No. 4, pp. 471-484.

49. Anderson, J. C., and Gerbing, D. W. (1988) 'Structural equation modeling in practice: A review and recommended two-step approach', Psychological Bulletin, Vol. 103, No. 3, pp. 411-423. 
50. Garver, M. S. and Mentzer, J. T. (1999) 'Logistics research methods: Employing structural equation modeling to test for construct validity', Journal of Business Logistics, Vol. 20, No. 1, pp. 33-57.

51. Fornell, C. and Larcker, D. F. (1981) 'Evaluating structural equation models with unobservable variables and measurement error', Journal of Marketing Research, Vol. 18, No. 1 39-50.

52. Cohen J. (1969) 'Statistical Power Analysis for the Behavioral Sciences', Academic Press Publishers, New York, NY.

53. Hutcheson, G. and Sofroniou, N. (1999) 'The Multivariate Social Scientist: Introductory Statistics Using Generalized Linear Models', Sage Publications, Thousand Oaks, CA.

54. Bentler, P.M., and Bonnet, D.G. (1980) 'Significance Tests and Goodness of Fit in the Analysis of Covariance Structures', Psychological Bulletin, Vol.88, No. 3, pp. 588-606.

55. Bentler, P. M. (1990) 'Comparative fit indices in structural models'. Psychological Bulletin, Vol. 107, No. 2, pp. 238-246.

56. Hair, J. F., Anderson, R. E., Tatham, R. L. \& Black, W. C. (1995). 'Multivariate Data Analysis with Readings', $4^{\text {th }}$ Edition, Prentice Hall International, Englewood Cliffs.

57. Browne, M. (1990), 'MUTMUM PC: User’s Guide', Ohio State University, Department of Psychology, OH.

58. Anderson, J.C. and Gerbing, D.W. (1991) 'Predicating the performance of measures in a confirmatory factor analysis with a pre-test assessment of their substantive validities', Journal of Applied Psychology, Vol. 76, No. 5, pp. $732-740$. 
59. Volkner, F., Sattler, H. and Kaufmann, G. (2008) 'Image feedback effects of brand extensions: Evidence from a longitudinal field study', Marketing Letters, Vol. 19, No. 2, pp. 109-124.

60. Lane, V. and Jacobsen R. (1995) 'Stock market reactions to brand extension announcements: The effects of brand attitude and familiarity', Journal of Marketing, Vol. 59, No. 1, pp.63-77.

61. Nijssen, E. J. and Agustin, C. (2005) 'Brand extensions: A manager’s perspective', Journal of Brand Management, Vol. 13, No. 1, pp. 33-49.

62. Carlotti, S. J. Jr, Coe, M. E. and Perry, J. (2004) 'Making brand portfolios work. An indepth look at the challenges facing senior managers', The McKinsey Quarterly, No. 4, pp. 24-35.

63. Farquhar, P. H. (1989) 'Managing brand equity', Journal of Marketing Research, Vol. 26, No. 1, 24-33.

\section{Acknowledgments}

The authors are immensely thankful to the reviewers for their valuable comments. The authors would also like to extend their gratitude to Dr. D.N. Dwivedi, Dr. N.K. Kakkar and their colleagues at the Maharaja Agrasen Institute for Management Studies (MAIMS), New Delhi, India for their valuable assistance. 